FOLIA POMERANAE UNIVERSITATIS TECHNOLOGIAE STETINENSIS

Folia Pomer. Univ. Technol. Stetin., Oeconomica 2017, 335(87)2, 103-112

Zdzisław KES, Tomasz DYCZKOWSKI

\title{
ZASTOSOWANIE GRY SYMULACYJNEJ W NAUCZANIU BUDŻETOWANIA NA UCZELNI
}

\author{
INTRODUCTION OF A SIMULATION GAME IN TEACHING BUDGETING \\ AT A UNIVERSITY
}

Katedra Rachunku Kosztów, Rachunkowości Zarządczej i Controllingu, Uniwersytet Ekonomiczny we Wrocławiu, ul. Komandorska 118/120, 53-345 Wrocław, e-mail: zdzislaw.kes@ue.wroc.pl

\begin{abstract}
Summary. Budgeting is one of the topics placed in syllabuses of subjects such as controlling, management accounting and cost accounting, carried out in various fields of higher education. A budgeting process, which is an item on the teaching agenda, includes setting up budgets tailored to a specific business activity and controlling their implementation. The control can be done in a number of cycles, and results thereof trigger corrective actions. According to the authors of this paper, students' understanding of this process, requires modern teaching techniques being used, including interactive computer simulations. The article presents an original concept of building a simulator of budgetary variances to be used in a budgeting tutelage at a university level.
\end{abstract}

Słowa kluczowe: budżetowanie, kontrola wykonania budżetów, symulatory w dydaktyce. Key words: budgeting, budgetary control, simulators in teaching.

\section{WSTĘP}

Budżetowanie ${ }^{1}$ koncentruje się na sporządzaniu planów działalności gospodarczej oraz na okresowej weryfikacji ich wykonania, co jest podstawą regulacji lub sterowania procesami gospodarczymi objętych planami. Pomimo wielu wad i uwag krytycznych dotyczących budżetowania stanowi ono jedno z częściej stosowanych w praktyce gospodarczej narzędzi rachunkowości zarządczej czy controllingu (Rachunkowość zarządcza... 2009; Handbook of budgeting 2012).

W związku z tym należy uznać za właściwe umieszczenie tej tematyki w standardach kształcenia na takich kierunkach studiów, jak: zarządzanie, zarządzanie i inżynieria produkcji oraz finanse i rachunkowość. Na tych kierunkach na studiach II stopnia w przedmiotach rachunek kosztów, rachunkowość zarządcza uwzględniono takie treści kształcenia, jak: koncepcje operacyjnego budżetowania kosztów przedsiębiorstwa, kontrola budżetowa kosztów, budżetowa metoda zarządzania (Rozporządzenie Ministra Nauki i Szkolnictwa Wyższego z dnia 12 lipca 2007 r.).

\footnotetext{
${ }^{1}$ Użyte w artykule pojęcie odnosi się do budżetowania operacyjnego.
} 
Nauczanie zagadnień związanych z budżetowaniem, w ramach wspomnianych wyżej przedmiotów, wiąże się ze znacznymi wymaganiami. Wymagania te wynikają nie tylko ze złożoności nauczanej materii, ale również z interdyscyplinarności poruszanych tematów. Zagadnienia obejmują: zarządzanie, rachunkowość finansową, rachunkowość zarządczą, rachunek kosztów, logistykę, planowanie produkcji, analizę ekonomiczną itp. Warto nadmienić, że koncentrowanie się podczas zajęć na metodach budżetowania, tworzeniu budżetów, ich optymalizacji, analizie odchyleń nie zapozna studentów, zdaniem autorów, z najważniejszą cechą budżetowania. Budżetowanie w praktyce funkcjonuje wg cyklu PDCA², czyli „zaplanuj - wykonaj - sprawdź - popraw”.

Zdaniem autorów niniejszego artykułu istotą nauczania w ramach wymienionych tematów w standardach kształcenia powinno być dostarczanie wiedzy, umiejętności i kompetencji w powiązanych ze sobą etapach: tworzenia systemu budżetowania, tworzenia budżetów cząstkowych, uzgadniania budżetów z celami strategicznymi, podejmowania decyzji operacyjnych zgodnie z odpowiednimi budżetami, analizowania wyników kontroli budżetowej, ustalania i monitorowania działań korygujących.

Biorąc pod uwagę powyższe rozważania, wydaje się uzasadnione to, że zajęcia dotyczące budżetowania powinny być prowadzone z wykorzystaniem technik nauczania oddających chociaż w minimalnym stopniu rzeczywiste warunki prowadzenia działalności gospodarczej. Dlatego autorzy niniejszego opracowania skierowali uwagę na gry symulacyjne, które mogą przyczynić się do zwiększenia skuteczności przekazywania wiedzy nt. stosowania budżetowania.

Celem niniejszego artykułu jest ustalenie istoty i zakresu zastosowania gry symulacyjnej, która pozwala na modelowanie zachowań menedżerów stosujących budżetowanie. Gra będzie wykorzystywana na zajęciach z controllingu dla studentów studiów I i II stopnia na kierunku finanse i rachunkowość. Na potrzeby badań wykorzystano wywiady ustrukturyzowane przeprowadzone z pracownikami naukowymi katedr zajmujących się nauczaniem controllingu na Uniwersytecie Ekonomicznym we Wrocławiu oraz ze studentami będącymi uczestnikami symulacji.

\section{WYKORZYSTANIE GIER SYMULACYJNYCH W NAUCZANIU}

Wykorzystanie gier w szkolnictwie wyższym stanowi dzisiaj standard. Taka forma zajęć często spotykana jest na kierunkach zarządzanie, logistyka, ostatnio również na finansach i rachunkowości. W związku z tym ciekawe pytanie zadaje Marjak (2009) w swoim artykule pt. „Ekonomiczne gry symulacyjne w środowisku wirtualnym”: Czy szkoła wyższa to miejsce na zabawę? Można na to pytanie odpowiedzieć twierdząco, ale z jednym zastrzeżeniem zabawa ma sens na uczelniach, ale tylko wtedy, gdy połączy się ją z nauką. To połączenie widoczne jest właśnie w przypadku gier dydaktycznych. Przez pojęcie „gra dydaktyczna” można rozumieć np.: „[...] celowo organizowaną sytuację, w której osoby uczące się konkurują ze sobą w ramach określonych reguł gry, swoistego konkretnego regulaminu tej gry" (Majgier-Dąbek 2013, http://www.soswprzem.pl/publikacje/gry.pdf). Dzięki zastosowaniu gier w edukacji można uczyć przez doświadczenie, pomagać w zrozumieniu podawanych treści, a poprzez mechanizm współzawodnictwa oraz atrakcyjną formułę można zachęcić studentów do czynnego uczestnictwa w zajęciach.

\footnotetext{
${ }^{2} \mathrm{O}$ zastosowaniu tego cyklu w doskonaleniu controllingu pisze m.in. Bieńkowska (2016).
} 
W niniejszym artykule zaproponowano zastąpienie pojęcia gry edukacyjnej i bardziej precyzyjnym pojęciem „gra symulacyjna”. Między tymi terminami występują zależności i podobieństwa, które należy wyjaśnić. Według Rizzi i Woźniakiewicz (2016) gra symulacyjna jest specyficznym połączeniem: gry, odgrywania ról oraz symulacji. Gra może być rozumiana jako zabawa towarzyska prowadzona według określonych zasad i reguł. Role pozwalają na wcielanie się studentów w konkretne osoby mające określone zadania, kompetencje, pola decyzyjne oraz odpowiedzialność. Natomiast symulacja jest pewnym modelem rzeczywistości, który najczęściej w uproszczony sposób pozwala na odtwarzanie warunków charakterystycznych dla danego zjawiska lub obiektu. Podobne rozumienie symulacji można znaleźć w opracowaniu Pietrzaka (2009). Dodatkowo wyjaśnia on różnice między symulacją a grą symulacyjną. Autor ten uważa, że w trakcie symulacji uczestnicy jedynie w minimalnym stopniu mogą współzawodniczyć ze sobą - na poziomie indywidualnym czy grupowym, a brak zwycięzców i pokonanych jest tym, co odróżnia symulację od gier symulacyjnych i edukacyjnych.

W związku z charakterystyką budżetowania oraz nauczaniem na uczelniach przyjęto wykorzystanie aktywnej techniki nauczania w postaci gry symulacyjnej. Zastosowanie tej formy powinno wpłynąć pozytywnie na motywację uczących się do udziału w zajęciach i do rozwiązywania problemów analogicznych do tych, z jakimi mogą się spotkać podczas kontaktu z budżetem w praktyce gospodarczej.

Definiując rodzaj gry, należy dodać, że prezentowana w artykule koncepcja zakłada zastosowanie komputerowej gry symulacyjnej. To wynika z konieczności przetwarzania dużych zbiorów danych ilościowych i finansowych w procesie budżetowania, co jest możliwe tylko w przypadku zastosowania odpowiednich aplikacji komputerowych.

W dalszej części niniejszego opracowania opisano koncepcję komputerowej gry symulacyjnej w prowadzeniu zajęć z budżetowania dla słuchaczy studiów ekonomicznych.

\section{METODY I WYNIKI}

Prace nad koncepcją gry symulacyjnej rozpoczęto w Katedrze Rachunku Kosztów Rachunkowości Zarządczej i Controllingu Uniwersytetu Ekonomicznego we Wrocławiu. Zespół projektowy postawił sobie za cel stworzenie modelu przedsiębiorstwa, który zostanie wykorzystany do prezentacji działania sprzężeń zwrotnych w ramach budżetowania operacyjnego. Model ten zostanie wykorzystany jako podstawa do budowy systemu budżetowania. Dzięki odwzorowaniu mechanizmów funkcjonowania przedsiębiorstwa, jak również aspektów rynkowych gracze będą mogli nie tylko wypełniać budżety zgodnie z przyjętymi samodzielnie celami strategicznymi i operacyjnymi, ale również wpływać na ich układ czy testować różne metody ich tworzenia. Ponadto symulacja (uruchamiana w kilkunastu czy kilkudziesięciu cyklach) pozwoli na wygenerowanie wielu serii danych obejmujących ilość produkcji i sprzedaży, kosztów, przychodów, wyników finansowych itp. Na podstawie różnic między planami a ich realizacją gracze będą mogli podejmować, według swojego rozeznania, działania korygujące. W kolejnych cyklach, na podstawie dostarczanych informacjach o dokonaniach, będzie możliwa ocena tych działań i ewentualna ich zmiana. 
Jako główny cel dydaktyczny symulacji przyjęto zapoznanie studentów z funkcjonowaniem systemu budżetowania poprzez umożliwienie im podejmowania decyzji na szczeblu zarządzania operacyjnego, w warunkach presji wynikającej z potrzeby osiągnięcia celów budżetowych. Przy tym możliwa jest realizacja następujących celów szczegółowych:

- zapoznanie się z procedurą budowy systemu budżetowania dla modelowego przedsiębiorstwa;

- zapoznanie się z elementami wchodzących w skład systemu budżetowania i z powiązaniami między nimi;

- praktyczne zapoznanie się z metodami budżetowania;

- ukazanie powiązań między parametrami ilościowo-wartościowymi, przyjmowanymi na etapie wypełniania budżetów, z celami strategicznymi przedsiębiorstwa;

- nauczenie metod analizy odchyleń budżetowych;

- pokazanie różnorodności raportów kontrolnych stosowanych w budżetowaniu;

- kształtowanie postaw odpowiedzialności za przyjęte cele i za proces ich realizacji.

Warto nadmienić, że z uwagi na problematykę związaną z nauczaniem controllingu na kierunku finanse i rachunkowość nie zakłada się wykorzystywania omawianej gry do nauczania rozliczeń podatkowych, prowadzenia rachunkowości czy sprawozdawczości finansowej.

Biorąc pod uwagę powyższe, przeprowadzono wywiad częściowo ustrukturyzowany, mający na celu określenie szczegółów gry symulacyjnej. Wywiad przeprowadzano z pracownikami Katedry Rachunku Kosztów, Rachunkowości Zarządczej i Controllingu oraz Katedry Rachunkowości, Controllingu, Informatyki i Metod Ilościowych. Dobór próby zakładał, że uczestnicy wywiadu w swojej karierze zawodowej prowadzili zajęcia z controllingu. Wszystkim uczestnikom wywiadu zadano następujące pytania otwarte:

1. Czy uważasz za uzasadnione wprowadzenie na zajęciach z controllingu komputerowej gry symulacyjnej wspomagającej nauczanie budżetowania?

2. Czy podstawą gry powinno być przedsiębiorstwo produkcyjne, handlowe czy usługowe?

3. Czy gra powinna wykorzystywać mechanizmy konkurencji między studentami?

4. Z ilu osób powinny składać się zespoły graczy?

5. lle czasu należy przeznaczyć na wprowadzenie do symulacji, rozgrywkę i omówienie wyników?

6. Czy gra powinna mieć zróżnicowane poziomy trudności?

7. Jakie decyzje powinni móc podejmować gracze w trakcie rozgrywki?

8. Jakimi cechami powinna się charakteryzować platforma informatyczna zastosowana do przeprowadzenia symulacji?

9. Na podstawie jakich parametrów należy oceniać studentów?

Po przeprowadzeniu wywiadów zebrano wszystkie informacje i dokonano ich konsolidacji.

Wyniki zaprezentowano $w$ tab. 1. 
Tabela 1. Odpowiedzi udzielone w wywiadzie nt. gry symulacyjnej wspomagającej proces edukacyjny dotyczący budżetowania

\begin{tabular}{|c|c|}
\hline $\begin{array}{c}\mathrm{Nr} \\
\text { pytania }\end{array}$ & Streszczenie odpowiedzi \\
\hline 1 & $\begin{array}{l}\text { Żaden z prowadzących nie stosuje gier edukacyjnych w trakcie zajęć z controllingu. Wszyscy pytani } \\
\text { byli zgodni, że w nauczaniu budżetowania symulator odchyleń budżetowych jest najlepszym } \\
\text { sposobem pokazania istoty budżetowania, jak również jego funkcjonowania w organizacji. Jedynym } \\
\text { ograniczeniem tej metody nauczania jest liczba godzin przeznaczonych na tematy obejmujące } \\
\text { budżetowanie, stąd pojawiał się postulat uproszczenia gry w taki sposób, aby można było skrócić } \\
\text { maksymalnie czas potrzebny na rozgrywkę }\end{array}$ \\
\hline 2 & $\begin{array}{l}\text { Respondenci mieli zróżnicowane opinie nt. wyboru rodzaju działalności dla modelowego przed- } \\
\text { siębiorstwa. Jednak większość z nich uważała, że budżetowanie kosztów przedsiębiorstwa pro- } \\
\text { dukcyjnego pozwala na pokazanie większej liczby rodzajów budżetu i co za tym idzie - metod ich } \\
\text { planowania, niż inne rodzaje jednostek gospodarczych. Pojawiały się również nieliczne głosy, aby } \\
\text { wykorzystać przedsiębiorstwo o profilu mieszanym, np. produkcyjno-usługowym czy usługowo- } \\
\text {-handlowym }\end{array}$ \\
\hline 3 & $\begin{array}{l}\text { Uczestnicy wywiadów przychylnie wypowiadali się nt. wykorzystania mechanizmów konkurencji } \\
\text { między studentami, jednakże wszyscy byli zgodni, że taka konkurencja spowoduje komplikacje } \\
\text { w ocenie wiedzy uzyskanej przez studenta }\end{array}$ \\
\hline 4 & $\begin{array}{l}\text { Według większości pracowników dydaktycznych biorących udział w wywiadzie gra symulacyjna } \\
\text { powinna obywać się w grupach kilkuosobowych, liczących od } 3 \text { do } 5 \text { osób }\end{array}$ \\
\hline 5 & $\begin{array}{l}\text { Respondenci odnieśli się pozytywnie do poziomów trudności gry, przy czym wskazali na potrzebę, } \\
\text { aby tych poziomów było nie więcej niż } 3 \text {. Z uwagi na brak możliwości porównywania ocen pracy } \\
\text { studentów grających na różnych poziomach trudności opcja ta powinna zostać wykorzystana przy } \\
\text { rozgrywkach prowadzonych na różnych poziomach studiów, np. najniższy poziom trudności dla } \\
\text { studentów studiów I stopnia, średni poziom trudności dla studentów studiów II stopnia, a najwyższy } \\
\text { poziom trudności dla słuchaczy studiów podyplomowych kształcących się w zakresie controllingu }\end{array}$ \\
\hline 6 & $\begin{array}{l}\text { Na podstawie udzielonych w wywiadzie odpowiedzi, na pytanie o czas trwania poszczególnych } \\
\text { etapów symulacji, ustalono przedziały z liczbą godzin lekcyjnych przeznaczonych na dany etap } \\
\text { symulacji. Czas przeznaczony na wprowadzenie do gry }-0,5-2 \mathrm{~h} \text {, na rozgrywkę }-4-8 \mathrm{~h} \text {, na } \\
\text { omówienie wyników rozgrywki }-0,5-2 \mathrm{~h}\end{array}$ \\
\hline 7 & $\begin{array}{l}\text { Zakres decyzji wg pytanych obejmuje następujące zagadnienia: ceny sprzedaży, odbiorców, akcje } \\
\text { promocyjne, kampanie reklamowe, plan produkcji, wielkość mocy produkcyjnych, inwestycje i re- } \\
\text { monty, liczbę nadgodzin, liczbę pracowników, jakość produkcji, ilość nabywanych materiałów, } \\
\text { dostawcę materiału, nowe produkty, innowacje }\end{array}$ \\
\hline 8 & $\begin{array}{l}\text { Najczęściej pojawiającą się kwestią w wywiadach był postulat braku konieczność prowadzenia zajęć } \\
\text { w laboratorium komputerowym. Respondenci uważali, że zajęcia można przeprowadzić z wy- } \\
\text { korzystaniem kilku laptopów zabezpieczonych przez prowadzących lub przyniesionych przez } \\
\text { słuchaczy. Ponadto większość uczestników wywiadu opowiedziała się za brakiem konieczności pracy } \\
\text { online. Odnośnie do cech aplikacji obsługującej grę najważniejsza okazała się możliwość } \\
\text { wykorzystania arkusza kalkulacyjnego na potrzeby analiz i raportowania dotyczącego danych } \\
\text { budżetowych. Jako istotne cechy platformy informatycznej w wywiadzie wskazano animacje procesu } \\
\text { produkcyjnego, dialogi z graczem, dostęp do internetu, mobilność aplikacji, możliwość rozbudowy gry }\end{array}$ \\
\hline 9 & $\begin{array}{l}\text { W zakresie oceny studentów odnotowano dwa poglądy, które wskazywały na ocenę na podstawie } \\
\text { maksymalizacji wyniku finansowego oraz minimalizacji uzyskanych odchyleń budżetowych }\end{array}$ \\
\hline
\end{tabular}

\section{PREZENTACJA KONCEPCJI GRY SYMULACYJNEJ}

Na podstawie raportu z przeprowadzonego wywiadu autorzy projektu stworzyli koncepcje gry symulacyjnej. Jako podstawę symulacji przyjęto jednostkę gospodarczą produkującą kaski - firmę FF-Helmets. Jednostka produkuje kaski motocyklowe integralne, szczękowe, motocrossowe, półotwarte oraz narciarskie i rowerowe. W trakcie gry pojawia się możliwość produkcji i sprzedaży 6 modeli kasków. FF-Helmets zatrudnia 33 pracowników, przy czym 
uczestnik symulacji nie będzie miał wpływu na ten parametr. W odniesieniu do kadry możliwe jest szkolenie pracowników, co ma przełożenie na koszty działalności, jakość produktów oraz skuteczność negocjacji zakupowych i sprzedażowych.

Symulacja obejmuje również proces produkcyjny, który składa się z 6 głównych faz: formowania wtryskowego, malowania skorupy, montażu osprzętu, przygotowania wkładu amortyzującego, kompletowania kasku oraz kontroli jakości. Do wyprodukowania każdego modelu kasku potrzebne są materiały niespecjalistyczne (granulaty oraz lakiery) oraz podzespoły (mocowania, osłony, wizjery, daszki, wyściółka, naklejki itp.) dostarczane przez podwykonawców. W trakcie symulacji będzie możliwe zarządzanie zapasami i dostawami dla 10 indeksów magazynowych.

Zasadniczym etapem produkcji każdego kasku jest formowanie wtryskowe. W parku maszynowym FF-Helmets przewidziano takie środki produkcji, jak: wtryskarki, szlifierki taśmowe, pompy i agregaty lakiernicze. Proces produkcyjny został zorganizowany w postaci dyskretnej (partiowej). Oznacza to, że podstawową jednostką produkcyjną jest jedna partia obejmująca 100 kasków jednego rodzaju. Czas produkcji partii wynosi średnio 20 roboczogodzin. Na ryc. 1 przedstawiono na wykresie Gantta szczegółowe etapy procesu produkcji wraz z ich czasem trwania.

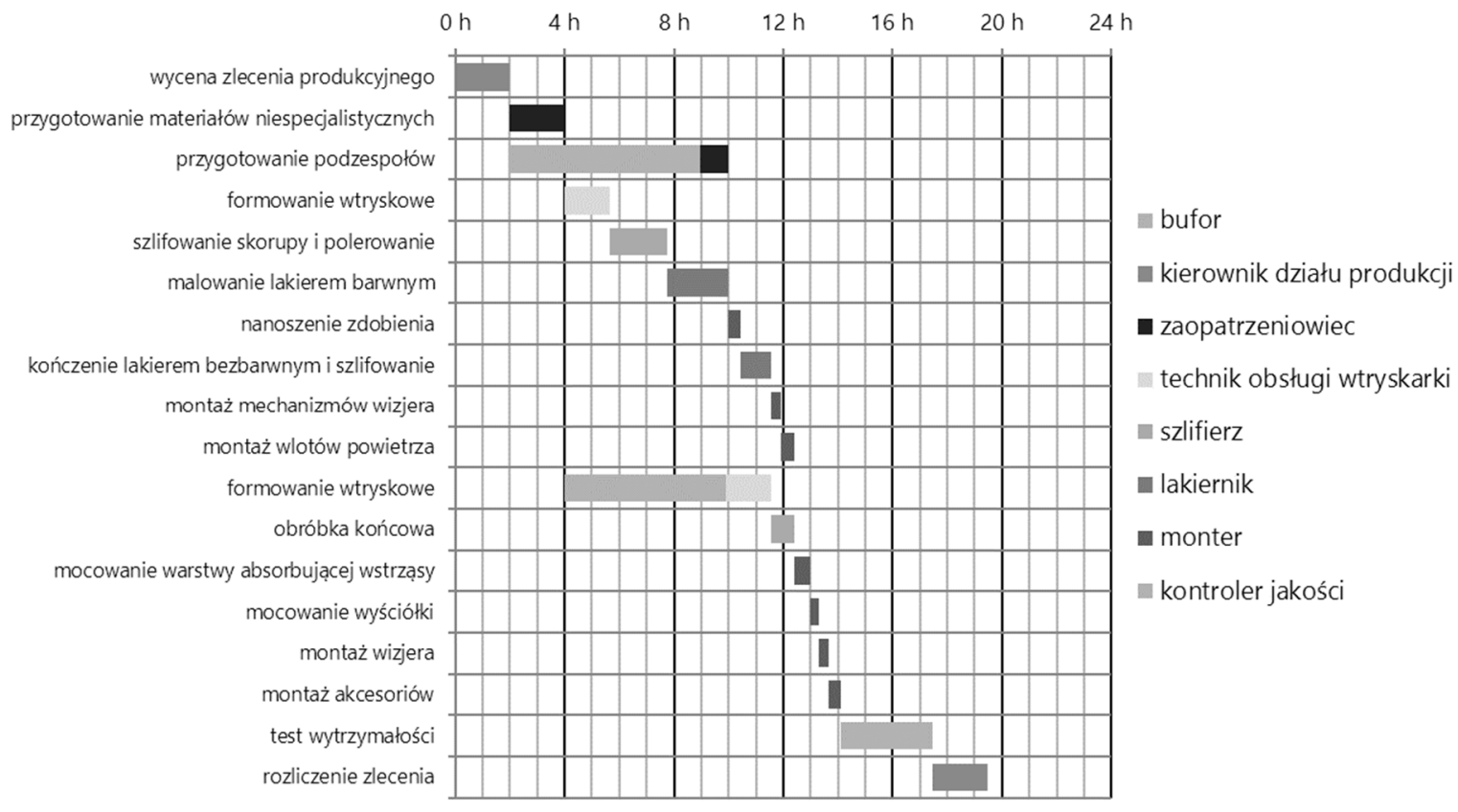

Ryc. 1. Proces produkcji kasku w FF-Helmets na wykresie Gantta Źródło: Opis gry symulacyjnej firmy FF Helmets (2016).

Sprzedaż produktów odbywa się na rynku, który jest autonomiczny. Oznacza to, że sprzedaż osiągana przez danego gracza nie wpływa na wyniki handlowe innych zespołów. Wielkość sprzedaży każdego z asortymentów jest obliczana na podstawie parametrów zadawanych przez prowadzącego, decyzji podejmowanych przez graczy, modelu cykliczności sprzedaży oraz czynników losowych. W tabeli 2 przedstawiono zmienne wpływające na wielkość sprzedaż każdego modelu. 
Tabela 2. Czynniki wpływające na sprzedaż

\begin{tabular}{|l|l|}
\hline \multicolumn{1}{|c|}{ Czynnik } & \multicolumn{1}{c|}{ Podmiot wpływający na czynnik } \\
\hline Poziom wyjściowy sprzedaży & prowadzący \\
\hline Sprzedaż w szczycie okresu & prowadzący \\
\hline Poziom maksymalny sprzedaży & prowadzący \\
\hline Poziom minimalny sprzedaży & prowadzący \\
\hline Długość trwania cyklu & prowadzący \\
\hline $\begin{array}{l}\text { Sezon występowania szczytu (w lecie lub } \\
\text { w zimie) }\end{array}$ & prowadzący \\
\hline Czynnik pogodowy wpływający na sprzedaż & $\begin{array}{l}\text { czynnik losowy z możliwością przewidywania przez gracza } \\
\text { na podstawie niepełnej informacji }\end{array}$ \\
\hline Inne zdarzenia wpływające na sprzedaż & czynnik losowy \\
\hline Akcje marketingowe i promocyjne & gracz \\
\hline Czynnik związany ze strategią cenową & gracz \\
\hline
\end{tabular}

Do dyspozycji gracza są wybrane elementy marketingu i promocji, za pomocą których może on oddziaływać na sprzedaż produktów. Do tych elementów zalicza się: sponsoring gwiazd sportu, telewizyjne kampanie reklamowe, wdrożenia nowych produktów, udział w targach motocyklowych itp. Koncepcja gry przewiduje również negatywne zmiany popytu (generowane losowo) na skutek wykrytych i ujawnionych wad produktów oraz nowości wprowadzanych przez konkurencję, a także prowadzonych kampanii reklamowych konkurencji.

W związku z dużym poziomem złożoności gry przewidziano możliwość rozgrywki w zespołach złożonych z 5 studentów. Poszczególni członkowie zespołu będą mogli się wcielić w jedną z ról: prezesa zarządu spółki, kierownika działu produkcji, kierownika działu sprzedaży, zaopatrzeniowca. Piąta osoba będzie miała do wyboru 3 stanowiska: stażysty w dziale księgowym, głównego księgowego, controllera. W związku z przyjęciem zasady o możliwości prowadzenia rozgrywki na różnych poziomach trudności wybór poziomu trudności wymaga przyjęcia przez piątego gracza jednej z 3 ról. Przy czym na najłatwiejszym poziomie dostępna jest rola stażysty, a na najtrudniejszym - rola controllera. Poszczególne poziomy rozgrywki różnią się wielkością popytu, widełkami czynników losowych, skutecznością akcji marketingowych, zdolnościami produkcyjnymi itp. Parametry zostały tak skalibrowane, aby graczom w roli stażysty łatwiej było osiągać cele budżetowe. Natomiast gracze wybierający rolę controllera będą musieli się wykazać większą pomysłowością i zaradnością, niż stażysta, jeżeli będą chcieli osiągnąć podobne wyniki. Przy wyborze roli księgowego rozgrywka będzie odbywała się na poziomie neutralnym.

Zróżnicowanie trudności pozwoli na grę studentom uczącym się na różnych poziomach. Zakłada się, że najłatwiejszy poziom będzie wykorzystywany na studiach licencjackich, poziom neutralny - na studiach magisterskich, a najtrudniejszy poziom - na studiach podyplomowych.

Czas rozgrywki jest dostosowany do rodzaju zajęć, na których wykorzystywana jest symulacja. Jak stwierdzono w wywiadach, zajęcia powinny trwać od 5 do 12 godzin lekcyjnych. Nie zawsze jednak siatka godzinowa danego przedmiotu przewiduje czas wystarczający na przeprowadzenie symulacji. Dlatego autorzy postanowili wykorzystać grę ze zmienną liczbą tur. Podstawowym elementem rozgrywki jest tura obejmująca: 
1) analizowanie danych dotyczących dostępnych zasobów oraz możliwych działań w ramach panelu decyzyjnego;

2) podejmowanie decyzji oraz wprowadzenie ich do panelu decyzyjnego;

3) rozpoczęcie symulacji, w czasie której na podstawie algorytmów oraz parametrów wprowadzonych przez graczy zostaną obliczone i przedstawione dane nt. wyprodukowanych i sprzedanych kasków, kosztów i przychodów oraz szczegółowe dane dotyczące zużytych zasobów, jakości produkcji, skutków oddziaływania czynników losowych na wyniki;

4) ocenę otrzymanych danych oraz wyciąganie wniosków, które mogą zostać wdrożone w kolejnych turach.

Według założeń autorów symulacji przedstawione etapy są częścią procesu rocznego budżetowania. Po przygotowaniu budżetów oraz ich zatwierdzeniu na początku rozgrywki każdy zespół będzie się starał o dokończenie gry z możliwie najmniejszymi odchyleniami. Oznacza to, że w każdej turze gracze powinni tak podejmować decyzje, aby osiągnąć cel w postaci minimum odchyleń. Dlatego jedynym parametrem wpływającym na czas gry jest liczba tur. W związku z przyjęciem dla budżetów miesięcznych okresów zakłada się 3 granulacje trwania tury: miesięczną, dwutygodniową oraz tygodniową. Daje to całkowitą liczbę tur wynoszącą odpowiednio 12, 24 i 48, co powinno umożliwić wystarczającą elastyczność, aby można było dostosować rozgrywkę do dostępnej liczby godzin lekcyjnych. Przy założeniu, że jedna tura będzie trwała od 5 do 10 min, otrzymujemy 6 możliwych długości czasu trwania rozgrywki (tab. 3).

Tabela 3. Czasy trwania tury oraz rozgrywki

\begin{tabular}{|l|r|r|r|r|r|r|}
\hline \multicolumn{1}{|c|}{ Liczba tur } & 48,0 & 48,0 & 24,0 & 24,0 & 12,0 & 12,0 \\
\hline Czas trwania tury [min] & 10,0 & 5,0 & 10,0 & 5,0 & 10,0 & 5,0 \\
\hline${\text { Czas rozgrywki [godz.] }{ }^{a}}^{\text {C }}$ & 10,7 & 5,3 & 5,3 & 2,7 & 2,7 & 1,3 \\
\hline
\end{tabular}

a Czas jest wyrażony w godzinach lekcyjnych trwających 45 min.

Jak pokazują dane z tab. 3, w zależności od zdolności graczy możliwe jest bardzo elastyczne sterowanie czasem rozgrywki. Czas ten waha się od 1,3 godziny lekcyjnej do 10,7 godziny, co daje duże możliwości dopasowania do warunków wyznaczonych przez siatkę godzinową przedmiotu. Należy pamiętać, że do czasu rozgrywki należy doliczyć czas poświęcony na zapoznanie studentów z zasadami gry oraz czas potrzebny na omówienie wyników osiągniętych przez uczestników symulacji.

Istotną kwestią jest rodzaj platformy, która pozwala na wprowadzanie danych, obliczanie wyników oraz ich prezentację. Ponadto do wymagań należy dołączyć możliwość budowy i wypełniania budżetów oraz prezentacji raportów kontrolnych, wraz z przeprowadzaniem analiz odchyleń budżetowych. Biorąc to pod uwagę, nie dopuszcza się innych rozwiązań niż te, które zakładają wykorzystanie komputerów. Przyjęcie założenia, że istnieje dostęp do laboratoriów komputerowych, rozwiązuje kwestie sprzętowe. Jednakże przy braku takiej możliwości można przyjąć rozwiązanie, w którym każdy z zespołów będzie wyposażony w jeden komputer przenośny.

Przy rozpatrywaniu rodzaju platformy brano pod uwagę Flash, html5 oraz VBA (Visual Basic for Application). Pierwsze z rozwiązań nie zostało wybrane z uwagi na wysokie koszty stworzenia oprogramowania, w drugim pojawiło się ryzyko problemów z przesyłaniem danych 
do aplikacji odpowiedzialnej za tworzenie i kontrolę budżetów. Jako optymalne rozwiązanie na tym etapie realizacji gry przyjęto środowisko arkusza kalkulacyjnego, w którym symulacja jest obsługiwana przez język programowania VBA, a sam arkusz pozwala na przeprowadzanie dowolnych analiz danych pochodzących z gry.

Decyzja o wykorzystaniu MS Excela jako platformy dla gry przyniosła wiele korzyści. Powszechność tej aplikacji pozwala na uruchomienie gry na większości komputerów uczelnianych i prywatnych. Arkusz kalkulacyjny jest również dobrze znany studentom, w związku z czym nie ma potrzeby szkolenia z zakresu posługiwania się nim. Aplikacja ta jest przystosowana w wystarczającym stopniu do tworzenia budżetów oraz generowania raportów, co pozwoli na znaczne obniżenie kosztów tworzenia gry. Język VBA jest prostym językiem obiektowym, pozwalającym m.in. na automatyzację pracy $z$ danymi w skoroszytach MS Excela. Do tego posiada wiele obiektów w postaci okien dialogowych, list rozwijalnych, przycisków i in., które można wykorzystać jako interfejs dla gry. Wraz z niskimi kosztami tworzenia aplikacji w VBA oraz z możliwością szybkiej i bezkosztowej modyfikacji algorytmów gry tworzy obraz idealnego środowiska dla budowanej gry. Oczywiście, należy w tym miejscu wspomnieć, że MS Excel nie daje wielu możliwości w generowaniu zaawansowanej grafiki, a czego oczekiwała pewna część osób biorących udział w wywiadach.

Każdy etap procesu edukacyjnego powinien być ewaluowany. W przypadku omawianej symulacji istnieje wiele możliwości oceniania. Generalnie symulacja ma pokazywać, jak należy wykorzystywać budżety i raporty, aby za pomocą dostępnych narzędzi minimalizować odchylenia budżetowe. Przy czym w grze będą dostępne różne budżety cząstkowe, za które mogą być odpowiedzialni różni członkowie tego samego zespołu. Do kryterium oceny zostanie dodany parametr uzależniony od uzyskiwanych wyników finansowych z uwagi na różnicę w poziomie odchyleń dla budżetów, gdy są one „napięte” oraz gdy mają „luzy”.

Przedstawiona koncepcja jest oczywiście wynikiem prac przedwdrożeniowych całego procesu. Autorów czeka ogrom pracy związanej z implementacją algorytmów i mechanizmów gry do aplikacji stworzonej w VBA. Następną fazą będzie testowanie gry i jej parametryzowanie. Jednakże sukces całego projektu zależy w dużym stopniu od jakości prac w początkowych etapach produkcji gier.

\section{PODSUMOWANIE}

Komputerowe gry symulacyjne w określonych przypadkach stanowią alternatywę dla tradycyjnych form i technik nauczania. W przypadku kierunków studiów, na których pojawiają się tematy związane z budżetowaniem, wydaje się koniecznością wykorzystanie właśnie takich form i technik nauczania. Dzięki temu zaistnieje możliwość poruszenia wielu tematów w sposób nie tylko atrakcyjny dla słuchaczy, ale przede wszystkim nawiązujący do rzeczywistości gospodarczej. Do zalet związanych z wyborem tego rodzaju formy kształcenia należy zaliczyć:

- prezentację całego procesu budżetowania, a nie tylko jego wybranych etapów;

- zapoznanie słuchaczy z zależnościami między warunkami prowadzenia symulowanej działalności a systemem budżetowania;

- zapoznanie studentów ze sprzężeniem zwrotnym wymuszanym przez proces budżetowania; 
- pokazanie studentom, jak wyniki kontroli wykonania budżetów są powiązane z decyzjami menedżerów;

- wykorzystanie mechanizmów pracy zespołowej oraz współzawodnictwa.

$Z$ uwagi na początkowy etap prac nad grą symulacyjną należy dodać, że kolejnym etapem będzie produkcja aplikacji komputerowej, a następnie jej testowanie; dopiero po testach oraz ewentualnych poprawkach gra zostanie wdrożona na odbywających się zajęciach, w ramach studiów II stopnia, na kierunku finanse i rachunkowość.

\section{PIŚMIENNICTWO}

Bieńkowska A. 2016. O dojrzałości controllingu. Pr. Nauk. UE Wroc. 421, 25-34.

Rachunkowość zarządcza i rachunek kosztów w systemie informacyjnym przedsiębiorstwa. 2009. Red. A. Karmańska. Warszawa, Difin.

Handbook of budgeting. 2012. Red. W.R. Lalli. New Jersey, Wiley.

Majgier-Dąbek D. Korzyści płynące z zastosowania gier dydaktycznych w nauce chemii i biologii, http://www.soswprzem.pl/publikacje/gry.pdf, dostęp: 15.12.2013.

Marjak H. 2009. Ekonomiczne gry symulacyjne w środowisku wirtualnym. Oeconomica 273, 123-134.

Opis gry symulacyjnej firmy FF Helmets. 2016. Firma FF Helmets (materiały niepublikowane).

Pietrzak J. 2009. Symulacje i gry symulacyjne, czyli jak naśladujemy procesy społeczne, www.ceo.org.pl/ /sites/default/files/news-files/symulacje_i_gry.pdf, dostęp: 3.02.2017.

Rizzi P., Woźniakiewicz J.M. 2008. Perspektywy zastosowania gier symulacyjnych w edukacji - teoria i praktyka. Homo Comm. 3, 57-64.

Rozporządzenie Ministra Nauki i Szkolnictwa Wyższego z dnia 12 lipca 2007 r. w sprawie standardów kształcenia dla poszczególnych kierunków oraz poziomów kształcenia, a także trybu tworzenia i warunków, jakie musi spełniać uczelnia, by prowadzić studia międzykierunkowe oraz makrokierunki. DzU z 2007 r., nr 164, poz. 1166. 